Article

\title{
Energy Performance of Two Multi-Story Wood-Frame Passive Houses in Sweden
}

\section{Krushna Mahapatra ${ }^{1, *}$ and Stefan Olsson ${ }^{2}$}

1 Department of Built Environment and Energy Technology, Linnaeus University, SE-35195 Växjö, Sweden

2 Energy Agency for Southeast Sweden, 35246 Växjö, Sweden;

E-Mail: stefan.olsson@energikontorsydost.se

* Author to whom correspondence should be addressed; E-Mail: krushna.mahapatra@lnu.se; Tel.: +46-470-767813.

Academic Editor: Kheir Al-Kodmany

Received: 7 September 2015 / Accepted: 3 November 2015 / Published: 10 November 2015

\begin{abstract}
Two eight-story wood-framed residential buildings with the Swedish 2012 passive house standard were built in 2009 in the Portvakten Söder quarter in the city of Växjö in Sweden. In this paper, we present the monitored specific energy use of the buildings and compare to the requirements of the Swedish building code and recommendation for passive houses. We also estimated the primary energy use and $\mathrm{CO}_{2}$ emissions and investigated the tenants' views and experiences of the two buildings. Results show that the actual specific energy use of $40.2 \mathrm{kWh} / \mathrm{m}^{2} \mathrm{~A}_{\text {temp}} /$ year in the Portvakten Söder building fulfills, by a good margin, the requirements of the Swedish building code and the recommended passive house standard, but is higher than projected. Applying a marginal perspective, the calculated primary energy use and carbon dioxide emission from operating the buildings (excluding household electricity) was $40 \mathrm{kWh} / \mathrm{m}^{2} \mathrm{~A}_{\text {temp }} /$ year and zero, respectively. Responses of 20 tenants to a mail-in questionnaire survey showed that over $90 \%$ were satisfied with their apartments.
\end{abstract}

Keywords: passive house; wood building; energy use; monitoring; behavior 


\section{Introduction}

In the quest for reducing energy use and mitigating climate change, increased attention is paid to the energy efficiency of the building sector, which accounts for about $40 \%$ of the final energy use in Europe. The European Union's Energy Performance of Buildings Directive (EPBD) in 2010 requires that the Member States must establish and apply minimum energy performance requirements for new and existing buildings and also requires the Member States to ensure that by 31 December 2020, all new buildings are nearly zero-energy buildings. To fulfill the first requirement, Sweden has introduced the "specific energy use" concept in its building code. Specific energy use is the purchased energy for space heating, hot water, comfort cooling and facility electricity to operate the building, including that which is used in common areas. In other words, specific energy use is the purchased energy use excluding electricity for household purposes. The building codes (BBR) from 2006 onwards have set verifiable maximum specific energy use levels for new residential buildings. The values for the year 2014 are reported in Table 1. Construction of low energy houses, such as passive houses, is also increasingly promoted in Sweden. For example, the Lågan program is a collaborative project between the Swedish Construction Federation, the Swedish Energy Agency, Region Västra Götaland, Formas and others to support (including financially) the development of very low energy buildings in Sweden. The recommended standards for the passive houses have been developed by the Forum för energieffektiva byggnader (FEBY) [1], and the values for the year 2012 (FEBY 2012) are also presented in Table 1.

Table 1. Specific energy use of residential buildings in Sweden according to the requirements of the building code (BBR) and the recommended Forum för energieffektiva byggnader (FEBY) 2012 passive house standard.

\begin{tabular}{|c|c|c|c|c|}
\hline \multirow{3}{*}{ Climate Zone } & \multicolumn{4}{|c|}{ Maximum Annual Purchased Energy (kWh/m² $\left.\mathbf{A}_{\text {temp }}\right)$} \\
\hline & \multicolumn{2}{|c|}{ BBR 2014 (Mandatory) } & \multicolumn{2}{|c|}{ FEBY 2012 (Recommended) [1] } \\
\hline & $\begin{array}{c}\text { Buildings with } \\
\text { Electric Heating }\end{array}$ & Other Buildings & $\begin{array}{c}\text { Buildings with } \\
\text { Electric Heating }\end{array}$ & $\begin{array}{c}\text { Other } \\
\text { Buildings }\end{array}$ \\
\hline I (north Sweden) & 95 & 130 & 29 & 58 \\
\hline II (central Sweden) & 75 & 110 & 27 & 54 \\
\hline III (south Sweden) & 55 & 90 & 25 & 50 \\
\hline
\end{tabular}

Note: $\mathrm{A}_{\text {temp }}$ is the indoor floor area with a minimum temperature of $10^{\circ} \mathrm{C}$.

The Swedish residential and service sector accounted for about 38\% of the national final energy use in 2011, 60\% of which was used for space heating and hot water purposes [2]. The Swedish policy aims to reduce specific energy use in buildings by $50 \%$ by 2050 [3] compared to $261 \mathrm{kWh} / \mathrm{m}^{2}$ in 1995 [4]. Increased construction of high energy standard buildings, such as passive houses, contributes to achieving this goal, as they significantly reduce the operational phase energy use, but at the cost of increased energy use to produce the buildings [5]. Using wood frames instead of concrete reduces the buildings' production energy use by up to 30\%, and there are large potentials for energy recovery at the end of life of the wood-frame buildings [5]. Furthermore, life cycle $\mathrm{CO}_{2}$ emissions of wood-frame buildings is significantly reduced, mainly because the manufacturing of most wood products uses less fossil energy than the manufacturing of other materials, and by-products of wood processing can be used as biofuel to replace fossil fuel, while carbon is stored in wooden materials (sequestration). In addition, 
a wood-frame building uses a lesser quantity of cement than a concrete-frame building and, therefore, emits less cement reaction-related $\mathrm{CO}_{2}$ emissions $[5,6]$.

In Växjö city, located in the south of Sweden, two eight-story wood-framed residential buildings (Hus 28 and Hus 30) with the passive house standard were built in 2009 in the Portvakten Söder quarter (Figure 1). The aim of this paper is to compare the monitored specific energy use of the buildings with the projected values [7], the Swedish building code and the passive house standard for district-heated buildings located in Southern Sweden (Climate Zone III). Energy monitoring is necessary to ensure that actual energy use meets the projections and set standards. Monitoring of some of the low energy building projects in Sweden [8-12] and internationally [13-15] showed that actual energy use was higher than projected, but 25\%-50\% less than that of recent conventional buildings [15-17].

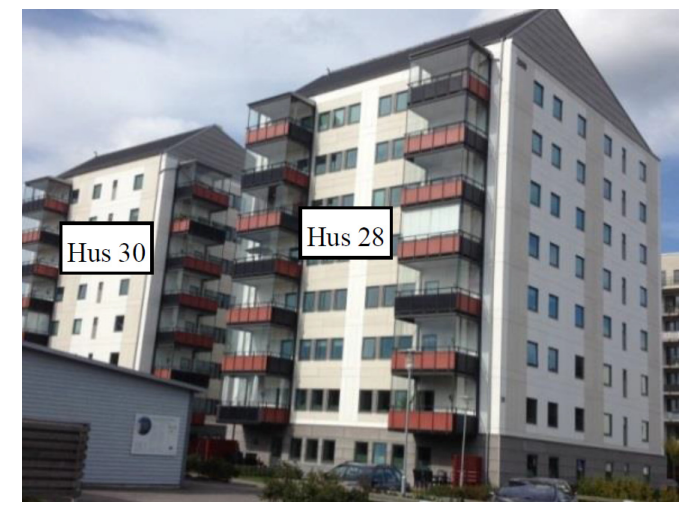

Figure 1. Two wood-framed passive houses in Portvakten Söder.

In a cold climate country like Sweden, passive houses can have a space heating system, at least as a back-up and also to supply hot water. There have been discussions about the environmental implications of installing different heating systems. For example, Gustavsson and Joelsson [18] reported that a traditional house connected to a biomass-based district heating system with combined heat and power (DH-CHP) production has lower primary energy use and $\mathrm{CO}_{2}$ emissions than a passive house with resistance heaters. Several other studies [19-21] also reported that biomass-based DH-CHPs are associated with low primary energy use and $\mathrm{CO}_{2}$ emission. However, those studies are based on the simulated energy demand of the buildings. We use the monitored energy use data to estimate the primary energy use and $\mathrm{CO}_{2}$ emissions from operating the Portvakten buildings with the existing district heating system. Similar estimations are made for scenarios where the buildings were heated with only bedrock heat pumps, air-source heat pumps or resistance heaters, which are common in the large part of the Swedish building stock.

We also investigated the tenants' views and experiences of the two buildings. If they have negative perceptions or experiences, they may pass that information on to other potential occupants through word-of-mouth [22], and that may hamper the long-term development of wood-framed passive houses in Sweden. Occupants of passive houses in Lindås in Sweden reported being unhappy with the indoor temperature, as they did not know how to use the ventilation system or how to control the heating system [23]. Other studies have shown that $80 \%$ of the tenants of wood frame buildings in the Swedish cities Växjö [24,25] and Sundsvall [26] liked to live in the wooden buildings. Still, some of them complained about the sound quality of the apartments, and many were unaware that they were moving into a wooden 
building [26]. There are several international studies that showed that people like to live in wooden buildings, but that they also have negative perceptions concerning the durability, stability, combustibility and acoustic insulation of wooden frames and the sustainability aspect of wood procurement $($ see $[27,28]$ for a summary).

Another study similar to ours was conducted in 2010 for one of the Portvakten Söder buildings, and the results were reported in 2013 [29]. However, in 2010, the building was half occupied. Hence, the study used various assumed values to convert the energy use data of the half-occupied building to that of a fullyoccupied building and found that the actual specific energy use would be higher than projected. In 2012, the buildings were fully occupied, which provides a better basis for the energy evaluation, as there is no need to assume the energy use behavior of the tenants. Moreover, we report the energy use for both buildings and additionally estimate the primary energy use and carbon dioxide emissions.

\section{The Buildings}

The two passive houses (Hus 28 and Hus 30) are located adjacent to each other in Portvakten Söder, and they are the tallest wood-framed passive houses in Sweden. The technical details of the buildings can be found in Kildsgaard et al. [29]. Both buildings have an identical design of the building's envelope, structure and technical systems. The slab-on-ground, the ground floor and the first intermediate floor are constructed in concrete in situ. The other floors are made up of prefabricated cross-laminated wood frames. The $U$-values of the windows, external walls and roof were less than $1 \mathrm{~W} / \mathrm{m}^{2} \mathrm{~K}, 0.11 \mathrm{~W} / \mathrm{m}^{2} \mathrm{~K}$ and $0.075 \mathrm{~W} / \mathrm{m}^{2} \mathrm{~K}$, respectively [29].

Each building has 32 apartments, but the total heated floor area $\left(\mathrm{A}_{\text {temp}}\right)$ and the size of the apartments vary (Table 2) between the buildings. In each apartment, there is a device to control indoor temperature and a heat exchanger, but there are no conventional radiators. Both buildings are connected to the local biomass-based DH-CHP for hot water and supplementary space heating through the heat exchanger. Each building has a central mechanical ventilation-with-heat recovery system with an efficiency of about 85\%. A waste water heat exchanger is installed and located underground between the two buildings. Metering devices are installed in each apartment to measure household electricity, cold water and hot water use, as well as energy loss from hot water circulation. In each building, there is a meter to read the facility's electricity use, but the meter in Hus 30 also records the electricity use of other areas outside the building, such as storage rooms and motor heating.

Table 2. Type of apartments in the Portvakten Söder buildings.

\begin{tabular}{|c|c|c|c|c|}
\hline \multirow{2}{*}{ Apartments } & \multicolumn{2}{|c|}{ Hus $28\left(A_{\text {temp }}=3270 \mathrm{~m}^{2}\right)$} & \multicolumn{2}{|c|}{ Hus $30\left(A_{\text {temp }}=2683 \mathrm{~m}^{2}\right)$} \\
\hline & Number & Floor Area & Number & Floor Area \\
\hline 2 rok & 1 & $63.6 \mathrm{~m}^{2}$ & 17 & $60-63.5 \mathrm{~m}^{2}$ \\
\hline 3 rok & 15 & $78.1-81 \mathrm{~m}^{2}$ & 15 & $77.9-80.2 \mathrm{~m}^{2}$ \\
\hline 4 rok & 16 & $94.5 \mathrm{~m}^{2}$ & 0 & - \\
\hline
\end{tabular}

Note: rok—rooms (including bedroom and living room) and kitchen. 


\section{Method}

Monthly data on purchased electricity for household and facility purposes and thermal energy for space heating and hot water purposes for each building were collected for the calendar year 2012 (January-December) from the building owner Hyresbostäder (now Växjöbostäder). Space heat demand of a building can vary from year to year depending on if it was a cold or a warm year. We have used the "heating degree days (HDD)" method to normalize the impact of such weather variations on the heat demand of the buildings. For a base temperature of $17^{\circ} \mathrm{C}$ (used by the Swedish Meteorological and Hydrological Institute), the HDD for Växjö in 2012 was 3544, and that of a normal year (average of 1960-1990) was 3577 [30]. The ratio 1.009 (degree days in a normal year divided by degree days in 2012) is the normalizing factor. The actual energy use for heating a building was multiplied by 1.009 to reach the normal heat demand of the building.

Energy use for hot water was calculated from the volume of hot water used and the energy use of 1.16 $\mathrm{kWh}$ to raise the temperature of $1 \mathrm{~m}^{3}$ of water by $1^{\circ} \mathrm{C}$ [29]. We have assumed that in Portvakten Söder, the incoming cold water is first preheated from an annual average temperature of $6{ }^{\circ} \mathrm{C}-10{ }^{\circ} \mathrm{C}$ in the waste water heat exchanger (following citations and measurements by Vändal and Lowentoft [31]) and then to $57^{\circ} \mathrm{C}$ in the heat exchanger connected to the district heating system. Results on energy use for hot water purposes include energy loss from hot water circulation.

In a district-heated building, the delivered district heat is metered at the heat exchanger, which is located outside the Portvakten Söder buildings. We have assumed a heat loss of 5\% [32] from the heat exchanger and from the heat distribution pipes to deliver the heat to the buildings. Therefore, the final space heating demand of the buildings was calculated to be $95 \%$ of the metered value. This estimated final space heating demand of the buildings was used to calculate the specific energy use, primary energy use and $\mathrm{CO}_{2}$ emissions, if the buildings had alternative heating systems, such as resistance heaters, airsource heat pumps or bedrock heat pumps. The electricity needed to fulfil the heat demand would vary with the coefficient of performance (COP) of the heat pumps, which we assumed to vary from 2.86 to 4 (energy saving of 65\%-75\%) for a bedrock heat pump and 2-3.33 (energy savings of 50\%-70\%) for an air-source heat pump [33]. The efficiency of resistance heaters is assumed to be $99 \%$.

The details of the district heating system are that of the DH-CHP production plant in Växjö, which generated 619.2 GWh of heat in 2011. The share of different production technologies and their conversion efficiencies are presented in Table 3. The distribution losses in district heat and electricity supply were assumed to be $13 \%$ [34] and 7\% [35], respectively. The fuel cycle losses were assumed to be $1 \%, 5.5 \%, 10 \%$ and $1.3 \%$ for biomass, oil, coal [36] and peat [37], respectively. 
Table 3. Share of different production technologies and their conversion efficiencies in the district heating (DH)-CHP production plant in Växjö, 2011.

\begin{tabular}{|c|c|c|c|}
\hline \multirow[t]{2}{*}{ Technology and Fuel } & \multirow[t]{2}{*}{ Share $(\%)$} & \multicolumn{2}{|c|}{$\begin{array}{c}\text { Conversion Efficiency, } \\
\text { Lower Heating Value (\%) }\end{array}$} \\
\hline & & Heat & Electricity \\
\hline \multicolumn{4}{|c|}{ Combined heat and power (CHP) plant } \\
\hline Biomass & 76.4 & 80 & 30 \\
\hline Peat & 5.8 & 80 & 30 \\
\hline Oil & 2.0 & 56 & 34 \\
\hline \multicolumn{4}{|l|}{ Heat-only boiler (HOB) } \\
\hline Biomass & 13.3 & 110 & - \\
\hline Oil & 2.4 & 90 & - \\
\hline
\end{tabular}

A system-wide perspective was applied, and all stages from extraction of raw materials to final energy use were included in the calculation of primary energy use and $\mathrm{CO}_{2}$ emissions from the operation of the buildings. Household electricity use was excluded, as it is not considered in the specific energy use concept. The primary energy values obtained for each type of fuel input to deliver heat (space heating and hot water) and facility electricity were added to obtain the total primary energy use of a building. The primary energy value of each fuel input was multiplied by its carbon content, and the sum was the $\mathrm{CO}_{2}$ emissions from a building. Sweden follows sustainable forest management practices, and therefore, biomass was assumed to be carbon neutral. Peat was considered as a fossil fuel [38]. The $\mathrm{CO}_{2}$ emission factor of peat was assumed to be $0.39 \mathrm{kgCO}_{2} / \mathrm{kWh}$ (or $107.3 \mathrm{kgCO}_{2} / \mathrm{GJ}$ ) following the guidelines of the Swedish Environmental Protection Agency [39].

CHP plants cogenerate heat and electricity, which creates an allocation issue in estimating primary energy use and $\mathrm{CO}_{2}$ emissions from district heat use only. We have avoided allocation following the recommendation of the International Organization for Standardization [40]. Instead, the subtraction method of systems expansion [41] was used. The primary energy use (or $\mathrm{CO}_{2}$ emission) of the cogenerated electricity, if that electricity were produced in a stand-alone power plant, was deducted from the total primary energy (or $\mathrm{CO}_{2}$ emission) of the CHP plant. We have applied a marginal accounting approach, which considers the marginal changes in the electricity supply system resulting from a unit change in electricity demand [42-44]. Weidema et al. [1] and the Swedish public investigation on energy efficiency of Swedish buildings [45] suggested that in prospective comparative studies, marginal technologies should be considered, as this gives the best reflection of the actual impact of a decision. We have assumed that, in the short-run, the additional electricity needed (if electric heating systems or heat pumps were installed in the buildings) or the surplus electricity from the CHP plant (existing district heating system) replaced electricity from coal-fired condensing power plants, as they are considered to be the marginal source of electricity in the Nordic countries at present [45]. The conversion efficiency of the coal-fired condensing plant was assumed to be $47 \%$ [46].

A mail-in questionnaire survey of the tenants was conducted to understand their experience of living in the passive houses. The questionnaire included questions about tenants' awareness of the type of building in which they are living, their overall satisfaction with the apartments, the experience of thermal comfort, sound insulation, energy use awareness, energy saving behavior, etc. Questionnaires were 
delivered to the 64 tenants in May 2013, and we received 20 responses. The low response rate of 31\% may influence the reliability of the survey results, and therefore, the results should be used cautiously. Therefore, it was not meaningful to show the results for each building.

\section{Results}

\subsection{Energy Use}

A comparative assessment of the energy use of the buildings is presented in Figure 2. Considering the average of both buildings, the actual total energy use (including household electricity) of $65 \mathrm{kWh} / \mathrm{m}^{2} A_{\text {temp}} /$ year in 2012 was lower than the projected $68.7 \mathrm{kWh} / \mathrm{m}^{2} A_{\text {temp}} /$ year. However, the specific energy use (i.e., excluding household electricity) of $40.2 \mathrm{kWh} / \mathrm{m}^{2} \mathrm{~A}_{\text {temp}} /$ year was higher than the projected $36.4 \mathrm{kWh} / \mathrm{m}^{2} \mathrm{~A}_{\text {temp}} /$ year, mainly because the actual energy use for space heating was $40 \%$ (3.7 kWh $/ \mathrm{m}^{2} \mathrm{~A}_{\text {temp }} /$ year) higher than the projected value. Nevertheless, the specific energy use was lower than the FEBY 2012 passive house standard and less than half of the requirement under BBR 2014. It could also be seen that household electricity and hot water use have larger shares than space heating demand in the total energy use.

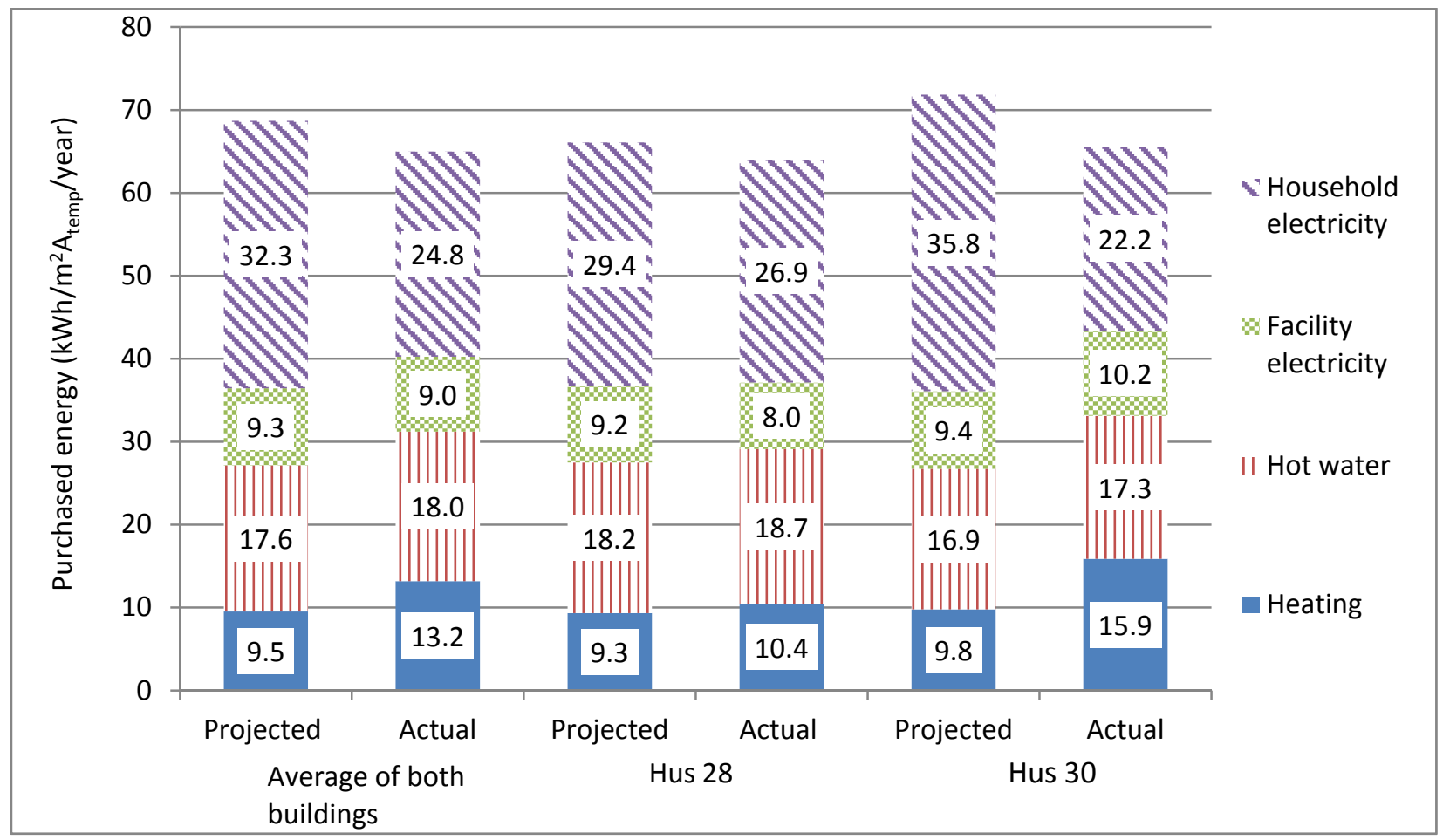

Figure 2. Projected (revised from [7]) and actual energy use in 2012 of the Portvakten Söder buildings. Energy use for heating is normalized.

Even though both buildings have the same technical standard, there were differences in energy use. The actual energy use for space heating in Hus 30 was about $60 \%$ higher than its projected value and 50\% higher than the actual energy use of Hus 28. Energy use for hot water purposes was rather similar in both buildings. Household electricity use in Hus 30 was about $17 \%$ lower than Hus 28. The facility electricity 
use of Hus 30 is higher than Hus 28, most likely because it includes the electricity use of the other areas. See Section 5 for a discussion of the differences in the energy performance of the buildings.

\subsection{Implication of Heating Systems}

Figure 3 shows that the average specific energy use would have been lower, but the average primary energy use and $\mathrm{CO}_{2}$ emissions would have been higher if the houses had heat pumps or electric resistance heaters. The results for heat pumps varied depending on the COP factor and are reflected in the error bars. The lower end is for a higher COP factor (i.e., lower specific energy use and, therefore, lower primary energy use and emissions) and vice versa. The average primary energy use and $\mathrm{CO}_{2}$ emission was the lowest with biomass-based district heating (DH-CHP), which is the existing heating system in the buildings.

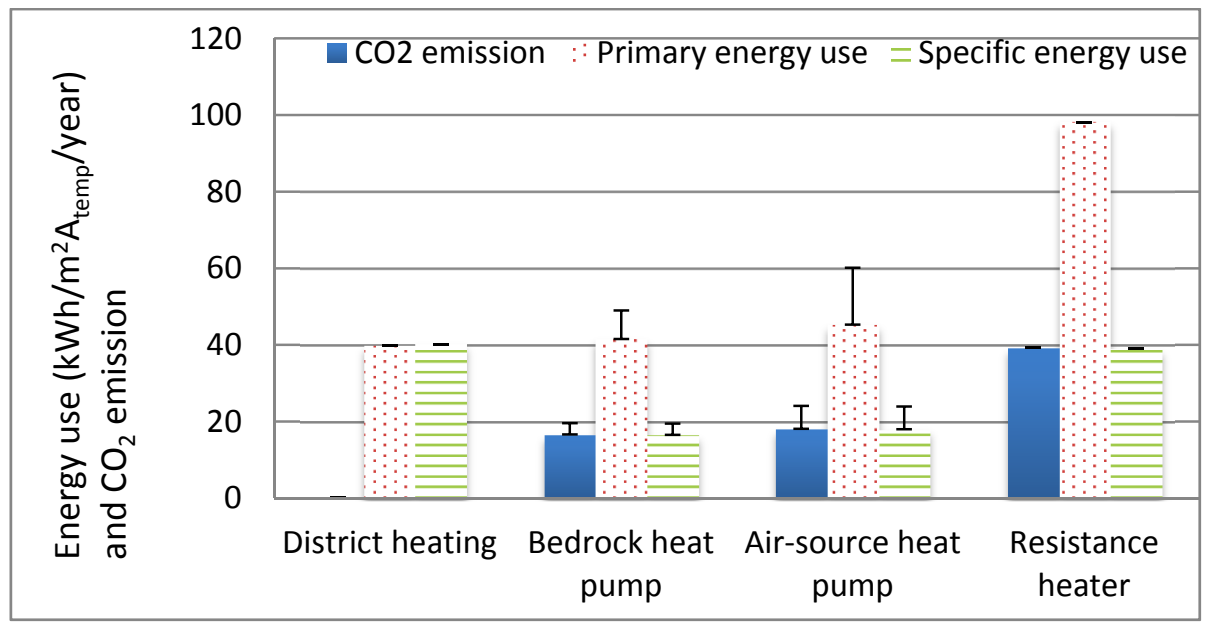

Figure 3. Average $\mathrm{CO}_{2}$ emission, primary energy use and specific energy use of both buildings with the existing district heating system vs. assumed alternative heating systems. The error bars for heat pumps show the range considering the coefficient of performance (COP) factors.

\subsection{Tenants' Experience}

The majority of the 20 respondents mentioned (yes/no option) that they knew that they lived in a passive house (87\%) and a wood-framed building (91\%). About 95\% reported that it was good or very good to live in the apartments. About $65 \%$ and $70 \%$ reported that the indoor thermal comfort was good or very good in summer and winter, respectively, but a relatively higher percentage thought that it was worse in summer (21\%) than in winter (10\%). About 22\% experienced a stuffy smell indoors, and $30 \%$ opened windows daily or several times a week during the winter months. Sound insulation of the wood-frame buildings seems to be acceptable, as $74 \%$ of the respondents felt that in general it was quiet or very quiet in their apartments. Still, $40 \%-60 \%$ of respondents felt there were sound problems from adjacent apartment/staircase/elevator or outside traffic/playing children.

About $70 \%$ and $80 \%$ of the respondents were aware of the quantity of electricity and hot water they used, respectively. However, 50\% did not know the cost of energy as a share of their household income (heating, hot water and electricity), and $45 \%$ indicated that it was less than $5 \%$ of the household 
income. Furthermore, a higher proportion of the respondents mentioned that it was important/very important for them to reduce electricity and hot water use for environmental reasons (65\%) than for cost reasons (44\%). Almost 95\% applied electricity saving measures, among which the most common was to switch off the appliances and lights when not in use and to use low-energy light bulbs (Figure 4). More than $80 \%$ of the respondents took some action to reduce hot water use. The most common measures included dishwashing without running water or showering with less hot water.

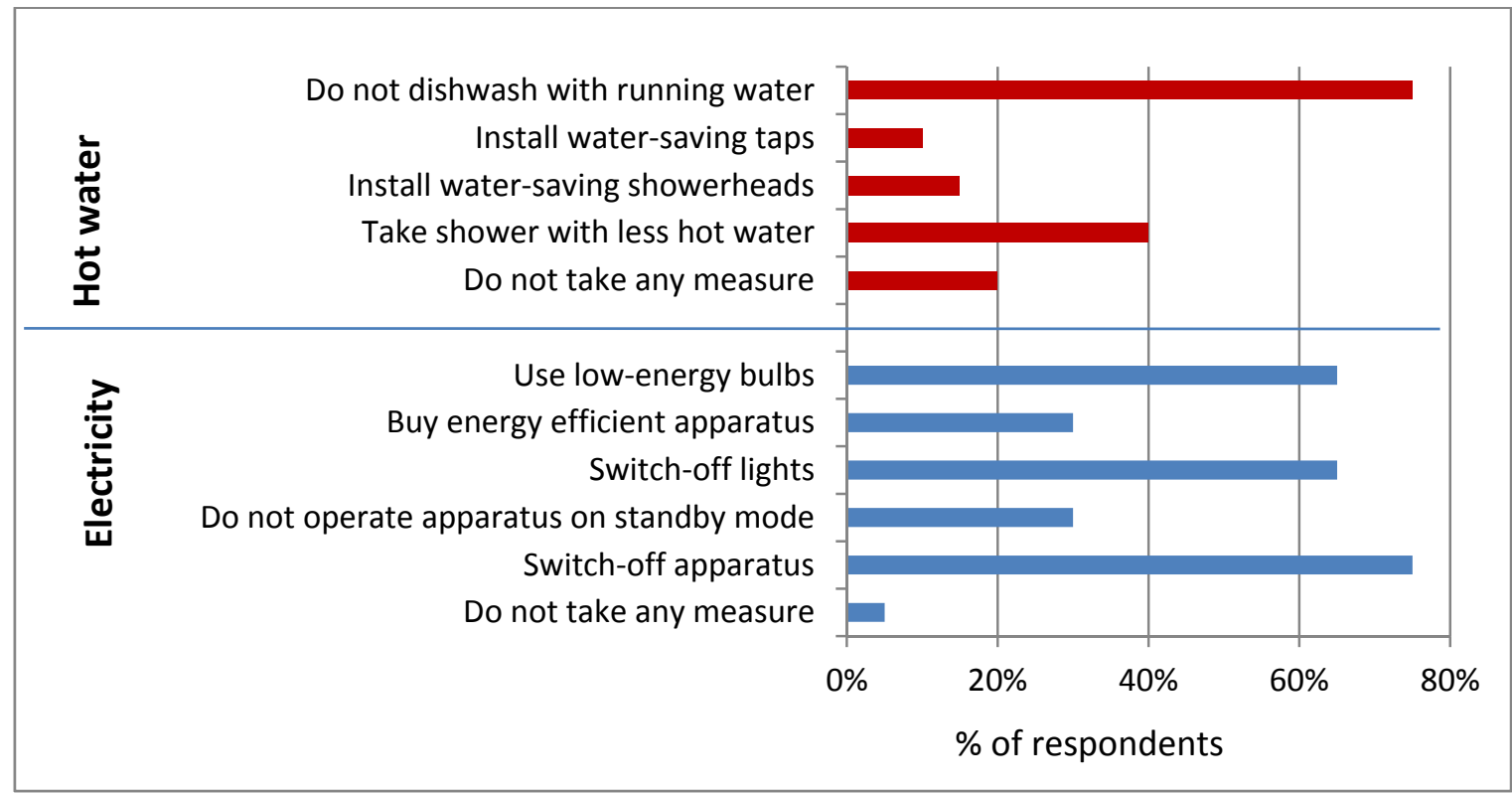

Figure 4. Measures taken by the tenants to reduce electricity and hot water use (the sum of percentages does not add to $100 \%$, as it was possible to mark several measures).

\section{Discussion}

The actual specific energy use in each of the Portvakten Söder buildings was lower than the FEBY 2012 standard and was less than half of the BBR 2014 requirement. However, the actual specific energy use was higher than projected, which was also found in other passive house projects in Sweden [9-12] and other countries [13-15]. Especially, in Hus 30, the space heating demand was 60\% higher than projected. A main reason for this could be that the actual household electricity use in both buildings was significantly lower than projected, which likely resulted in lower heat gain from this source, thereby increasing the space heating demand.

The indoor temperature profile could also explain the higher space heating demand of both buildings. In the energy projections, the annual average living area temperature was assumed to be $21^{\circ} \mathrm{C}$, but the actual average temperature during the heating season, October-April (Figure 5), which influences the heat demand, was a similar $21.9{ }^{\circ} \mathrm{C}$ in both buildings. From a site visit of the buildings, the authors also felt that the common area temperature might be few degrees Celsius higher than the assumed $15{ }^{\circ} \mathrm{C}$. A one degree higher indoor temperature means about 5\% higher energy demand [47]. Figure 5 also shows that there is no appreciable overheating problem. 


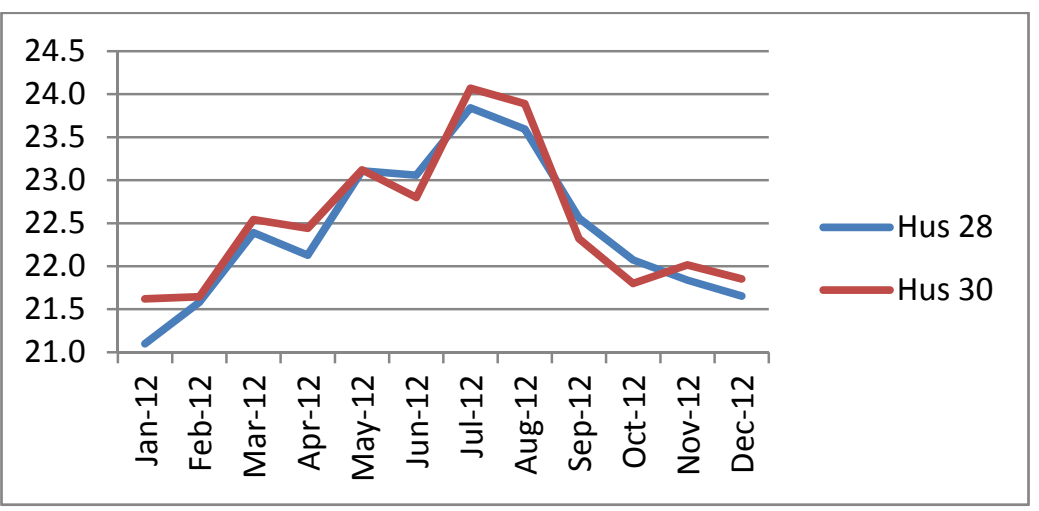

Figure 5. Monthly average living area temperature of the buildings in Portvakten Söder.

The actual space heating energy use in Hus 30 was $50 \%$ higher than in Hus 28 (5.4 kWh/m² Atemp/year), even though both buildings have the same technical specifications. In the following, we attempt to provide a few possible explanations for this variation, but we are aware that this is insufficient and that a more detailed analysis is needed.

Hus 30 was built first, and the experience might have resulted in the construction of a better airtight Hus 28. This indeed is the case. In the energy projections, the air-tightness of the building envelop of both buildings was assumed to be $0.20 \mathrm{~L} / \mathrm{s} \cdot \mathrm{m}^{2}$ at $\pm 50 \mathrm{~Pa}$ [7]. However, post-construction blower door testing of each (whole) building showed that the air-tightness was $0.15 \mathrm{~L} / \mathrm{s} \cdot \mathrm{m}^{2}$ and $0.19 \mathrm{~L} / \mathrm{s} \cdot \mathrm{m}^{2}$ at $\pm 50 \mathrm{~Pa}$ for Hus 28 and Hus 30, respectively [48]. Hus 30 is less air tight and, therefore, expected to have a marginally higher space heating demand than Hus 28 [49].

Other plausible explanations of the higher space heating demand of Hus 30 could be less heat gain from household electricity use and hot water use. Hus 30 has $23 \%$ less $A_{\text {temp }}$ and a greater number of two-room apartments than Hus 28. Hence, it is likely that more small-sized families lived in Hus 30, which resulted in lower electricity $\left(4.7 \mathrm{kWh} / \mathrm{m}^{2} \mathrm{~A}_{\text {temp }} /\right.$ year $)$ and hot water use $\left(1.4 \mathrm{kWh} / \mathrm{m}^{2} \mathrm{~A}_{\text {temp }} /\right.$ year $)$ than in Hus 28. The lower heat gained from these sources, as well as possibly lower internal heat gain from the inhabitants might have resulted in higher space heating demand [50] in Hus 30. Moreover, in smaller apartments (as in Hus 30), people may feel more locked-in and open the windows/doors quite often during the winter heating season. This was not possible to verify from our survey, but in general, about $22 \%$ of respondents experienced a stuffy smell indoor, and 30\% opened windows/doors daily or several times a week during the winter months. This might have increased the heat demand of the buildings.

The FEBY recommends that the household electricity and hot water use in low energy buildings should not exceed $30 \mathrm{kWh} / \mathrm{m}^{2} \mathrm{~A}_{\text {temp}} /$ year and $20 \mathrm{kWh} / \mathrm{m}^{2} \mathrm{~A}_{\text {temp}} /$ year (when each household pays for hot water separately), respectively. In the Portvakten Söder buildings, they were lower than recommended. Nevertheless, household electricity and hot water use constituted about $38 \%$ and $28 \%$ of the total actual energy use of the buildings, which is similar to measurements in other passive house projects in Sweden [9-12]. This suggests that with increased energy efficiency of buildings, greater attention should be given to reducing household electricity and hot water use. It is not enough to have a passive house; the tenant should also have energy saving attitudes and behaviors. About $65 \%$ of the respondents mentioned that it was important/very important for them to reduce electricity and hot water use for environmental reasons, which also leads to reduced energy cost. The most common electricity savings measures were to 
turn off the appliances and lights when not in use and to use low-energy light bulbs. The most common hot water savings measures include dishwashing without running water and showering with less hot water. Previous studies of tenants of passive apartment buildings showed that the tenants were engaged in energy saving behaviors to reduce monthly energy cost [9].

From an environmental point of view and applying the marginal perspective, the existing DH-CHP system in the buildings is the best alternative, as it has the lowest average primary energy use and $\mathrm{CO}_{2}$ emissions. Previous studies [19-21] also reported that biomass-based DH-CHPs are associated with low primary energy use and $\mathrm{CO}_{2}$ emissions. Alternative heating systems, such as resistance heaters or heat pumps, have lower specific energy use, which is metered and reflects a lower monetary energy cost, but they have greater environmental burdens. Hence, specific energy use is not an appropriate indicator of the environmental performance of the heating systems.

\section{Conclusions}

Multi-story wood-framed passive houses are relatively new to Sweden, as well as to Europe. Monitoring of these buildings is useful to showcase if it is possible to build renewable-material-based buildings with low energy use and climatic impact. Our study of the Portvakten Söder buildings shows that it is indeed possible. The specific energy use was lower than projected and that of the recommended passive house standard, and the primary energy use and $\mathrm{CO}_{2}$ emissions were minimum with the existing district heating system. Furthermore, more than $90 \%$ of the tenants were satisfied with their apartments (as was found in previous studies on passive houses $[9,16]$ ), and they took several measures to reduce electricity and hot water use. These suggest that wood-framed multi-story residential buildings built with the passive house standard have good market potential. This is a positive development to contribute to the EPBD directive that all new buildings in the EU Member States be nearly zero-energy buildings by 31 December 2020. Nonetheless, further research is needed to better understand the underlying factors contributing to the variation in the actual versus the projected energy performance of each building, as well as differences in the actual energy performance of both buildings.

\section{Author Contributions}

As the main author, Krushna Mahapatra conducted the analysis and wrote the paper. Stefan Olsson provided background information of the buildings and reviewed the manuscript.

\section{Conflicts of Interest}

The authors declare no conflict of interest.

\section{References}

1. Sveriges Centrum för Nollenergihus. Kravspecifikation för Nollenergihus, Passivhus och Minienergihus: Bostäder; LTH Rapport EBD-R-12/36; Available online: http://www. nollhus.se/dokument/ Kravspecifikation\%20FEBY12\%20-\%20bostader\%20sept.pdf (accessed on 10 October 2013).

2. Swedish Energy Agency. Energiläget 2013; ET 2013:22; Swedish Energy Agency: Eskilstuna, Sweden, 2013. 
3. Ett Energieffektivare Sverige. Slutbetänkande av Energieffektiviserings-Utredningen; SOU 2008:110; Government Offices of Sweden: Stockholm, Sweden, 2008.

4. Boverket. Energianvändning i Byggnader, Delmål 6-Underlagsrapport till Fördjupad Utvärdering av God Bebyggd Miljö 2007, November 2007; National Board of Housing, Building and Planning: Karlskrona, Sweden, 2007.

5. Dodoo, A.; Gustavsson, L.; Sathre, R. Lifecycle primary energy analysis of conventional and passive houses. Int. J. Sustain. Build. Technol. Urban Dev. 2012, 3, 105-111.

6. Gustavsson, L.; Pingoud, K.; Sathre, R. Carbon dioxide balance of wood substitution: Comparing concrete- and wood-framed buildings. Mitig. Adapt. Strateg. Glob. Chang. 2006, 11, 667-691.

7. NCC Construction Sverige AB. Energiberäkning Portvakten, Växjö; NCC Construction Sverige AB: Gothenberg, Sweden, 2008.

8. Lågan. LÅGANbygg-Marknadsöversikt, 2014. Available online: http://marknad.laganbygg.se/ lagan/www/index.php/ (accessed on 18 November 2014).

9. Jansson, U. Passive Houses in Sweden: From Design to Evaluation of Four Demonstration Projects. Ph.D. Thesis, Lund University, Lund, Sweden, 2010.

10. Aton. Verifierat Passivhus-Kv Fridhem, 2014. Available online: http://www.nollhus.se/images/ Rapporter/Verifierat_passivhus_Fridhem.pdf (accessed on 10 November 2014).

11. Wickman, P.; Sandberg, E. Lågenergihus_Jämförande + Mätstudie av Fyra Flerbostadshus. Ett LAGAN Finansierat Projekt; ATON Rapport 1301; Available online: http://www.aton.se/ img/userfiles/file/L\%C3\%A5genergihus\%20-\%20j\%C3\%A4mf\%C3\%B6rande\%20m\%C3\%

A4tstudie_maj.pdf (accessed on 10 November 2014).

12. Kilersjö, C.; Fahlén, E. Vallda Heberg, LÅGAN-Seminarium om Energieffektiva Byggnader 15 Oktober 2014. Available online: http://www.laganbygg.se/UserFiles/Hur_langt_kan/Elsa_ Fahlen_Presentation_LAGANs_seminariedag_141015_Vallda_Heberg_141007.pdf (accessed on 10 November 2014).

13. Majcen, D.; Itard, L.C.M.; Visscher, H. Theoretical vs. actual energy consumption of labelled dwellings in the Netherlands: Discrepancies and policy implications. Energy Policy 2013, 54, 125-136.

14. Wilde, P.D. The gap between predicted and measured energy performance of buildings: A framework for investigation. Autom. Constr. 2014, 41, 40-49.

15. Turner, C.; Frankel, M. Energy Performance of LEED ${ }^{\circledR}$ for New Construction Buildings; Final Report; Green Building Council: Washington, DC, USA, 2008. Available online: http://www.usgbc.org/Docs/Archive/General/Docs3930.pdf (accessed on 12 Nvember 2014).

16. Schnieders, J.; Hermelink, A. CEPHEUS Results: Measurements and occupants satisfaction provide evidence for passive houses being an option for sustainable building. Energy Policy 2006, 34, 151-171.

17. Danny Harvey, L.D. Recent advances in sustainable buildings: Review of the energy and cost performance of the state-of-the-art best practices from around the World. Annu. Rev. Environ. Resour. 2013, 38, 281-309.

18. Gustavsson, L.; Joelsson, A. Life cycle primary energy analysis of residential buildings. Energy Build. 2010, 42, 210-220. 
19. Gustavsson, L.; Joelsson, A.; Sathre, R. Life cycle primary energy use and carbon emission of an eight-storey wood-framed apartment building. Energy Build. 2010, 42, 230-242.

20. Gustavsson, L.; Joelsson, A. District heating and energy efficiency in detached houses of differing size and construction. Appl. Energy 2009, 86, 126-134.

21. Dodoo, A.; Gustavsson, L. Life cycle primary energy use and carbon footprint of wood-frame conventional and passive houses with biomass-based energy supply. Appl. Energy 2013, 112, 834-842.

22. Rogers, E.M. Diffusion of Innovations; Free Press: New York, NY, USA, 2003.

23. Jansson, U. Passive Houses in Sweden: Experience from Design and Construction Phase; Report EBD-T-08/9; Lund University, Lund, Sweden, 2008.

24. Schauerte, T. Evaluation of those who live in wooden buildings (Värderingarna hos dem som bor $\mathrm{i}$ trähus). Träinformation 2009, 2, 10.

25. Walford, G.B. Multistorey wood building in UK and Sweden. N. Z. Wood Des. J. 2006, 2, 6-13.

26. Boverket. Sundsvall's Inner Harbour-A Development and Information Project for Solid Wood Construction. (Sundsvalls Inre Hamn—Ett Utvecklings och Informationsprojekt för Trähusbyggande i Massivträ); Diarinummer 504-2239/2004; Available online: www.boverket.se (accessed on 5 November 2015).

27. Gold, S.; Rubik, F. Consumer attitudes towards wood as a construction material and towards wood frame houses-Selected findings of a representative survey among the German population. J. Clean. Prod. 2009, 17, 303-309.

28. Mahapatra, K.; Gustavsson, L. Multi-storey timber buildings-Breaking industry path dependency. Build. Res. Inf. 2008, 36, 638-648.

29. Kildsgaard, I.; Jarnehammar, A.; Widheden, A.; Wall, M. Energy and environmental performance of multi-storey apartment buildings built in timber construction using passive house principles. Buildings 2013, 3, 258-277.

30. Växjö Fastighetsförvaltning AB. Miljöredovisning för 2012. Available online: http://www.vaxjo.se/ upload/Profilerad\%20webbplats/V\%C3\%B6FAB/Bilder/bilder\%20p\%C3\%A5\%20sidor/milj\%C3 \%B6red\%20f\%C3\%B6r\%202012_1.pdf (accessed on 29 October 2013).

31. Vändal, S.; Lowentoft, C. Utvärdering av Portvakten Söders Spillvattenvärmeväxlare och Varmvattenförbrukning. Bachelor’s Thesis, Linnaeus University, Småland, Sweden, 2014.

32. Dodoo, A.; Gustavsson, L.; Sathre, R. Lifecycle carbon implications of conventional and low-energy multi-storey timber building systems. Energy Build. 2014, 82, 194-210.

33. Swedish Energy Agency. Välj rätt Värmepump; ET2010: 02; Swedish Energy Agency: Eskilstuna, Sweden, 2010.

34. Hördegård, U. Personal Communication with Ulf Hördegård, Project Leader; Växjö Energi AB: Växjö, Sweden, 2013.

35. Gustavsson, L.; Dodoo, A.; Truong, N.L.; Danielski, I. Primary energy implications of end-use energy efficiency measures in district heated buildings. Energy Build. 2011, 43, 38-48.

36. Gustavsson, L.; Sathre, R. Variability in energy and carbon dioxide balances of wood and concrete building materials. Build. Environ. 2006, 41, 940-951.

37. Uppenberg, S.; Zetterberg, L.; Åhman, M. Climate Impact from Peat Utilization in Sweden; IVL B-1423; Swedish Environmental Research Institute: Goeteborg, Sweden, 2001. 
38. Intergovernmental Panel on Climate Change. Climate Change 2007: Synthesis Report; IPCC: Geneva, Switzerland, 2007.

39. Swedish Environmental Protection Agency. Beräkna Utsläpp av Växthusgaser och Luftföroreningar. Available online: http://www.naturvardsverket.se/Stod-i-miljoarbetet/Vagledningar/Luft-och-klimat/ Berakna-utslapp-av-vaxthusgaser-och-luftfororeninga/ (accessed on 15 October 2014).

40. ISO 14044:2006 Environmental Management_Life Cycle Assessment-Requirements and Guidelines; International Standardization Organization: Geneva, Switzerland, 2010.

41. Gustavsson, L.; Karlsson, Å. A system perspective on the heating of detached houses. Energy Policy 2002, 30, 553-574.

42. Hawkes, A.D. Long-run marginal $\mathrm{CO}_{2}$ emissions factors in national electricity systems. Appl. Energy 2014, 125, 197-205.

43. Lund, H.; Mathiesen, B.V.; Christensen, P.; Schmidt, J.H. Energy system analysis of marginal electricity supply in consequential LCA. Int. J. Life Cycle Assess. 2010, 15, 260-271.

44. Harmsen, R.; Graus, W. How much $\mathrm{CO}_{2}$ emissions do we reduce by saving electricity? A focus on methods. Energy Policy 2013, 60, 803-812.

45. Weidema, B.P.; Frees, N.; Nielsen, A.-M. Marginal production technologies for life cycle inventories. Int. J. Life Cycle Assess. 1999, 4, 448-456.

46. Dodoo, A.; Gustavsson, L.; Sathre, R. Primary energy implications of ventilation heat recovery in residential buildings. Energy Build. 2011, 43, 1566-1572.

47. Energispartips: Värme. Swedish Energy Agency. 2014. Available online: http://www. energimyndigheten.se/Hushall/Tips-pa-hur-du-spar-energi--/Varme/ (accessed on 11 November 2014).

48. NCC Construction Sverige AB. Portvakten-Lufttäthetsprovning. Air Tightness Test Conducted by CA Consultadministration AB on behalf of NCC AB on 2009-02-18 (Hus 30) and 2009-06-24 (Hus 28); NCC Construction Sverige AB: Gothenberg, Sweden, 2009.

49. Dodoo, A. (Linnaeus University, Småland, Sweden). Personal Communication, 2015.

50. McMullan, R. Environmental Science in Building, 7th ed.; Palgrave Macmillan: Basingstoke, UK, 2012.

(C) 2015 by the authors; licensee MDPI, Basel, Switzerland. This article is an open access article distributed under the terms and conditions of the Creative Commons Attribution license (http://creativecommons.org/licenses/by/4.0/). 